\title{
APPLICATION OF WEBQUEST-BASED TEACHING MATERIALS ON DIGESTIVE SYSTEM TO IMPROVE LEARNING OUTCOMES AND MOTIVATION OF HIGH SCHOOL STUDENTS
}

\author{
Muhibbuddin $^{1 *}$, Wiwit Artika ${ }^{2}$, Nazar Muhammad ${ }^{3}$, Yaumil Istiqlal M.Nur ${ }^{4}$, Devi Syafrianti ${ }^{5}$ \\ ${ }^{1}$ Dr, Syiah Kuala University, Banda Aceh, Indonesia, muhibbuddin@unsyiah.ac.id \\ ${ }^{2}$ Dr. Syiah Kuala University, Banda Aceh, Indonesia, wartika@unsyiah.ac.id \\ ${ }^{3}$ Syiah Kuala University, Banda Aceh, Indonesia, nazarmuhammad@unsyiah.ac.id \\ ${ }^{4}$ Syiah Kuala University, Banda Aceh, Indonesia, yaumilistiglalmnur@unsyiah.ac.id \\ ${ }^{5}$ Syiah Kuala University, Banda Aceh, Indonesia, devi.syafrianti@unsyiah.ac.id \\ ${ }^{*}$ Corresponding Author
}

\begin{abstract}
Learning outcomes and motivation to learn are two important aspects that must be considered in learning. Learning outcomes and learning motivation can be achieved if teachers apply appropriate teaching media and learning models. The use of inquiry-assisted webquest teaching media is a combination of teaching media and learning models that can be applied in learning. This study aims to see the application of WebQuest - based teaching materials in improving learning outcomes and learning outcomes, as well as the response of high school students to the digestive system material. This study aims to observe the application of WebQuest-based teaching materials in improving learning outcomes and learning motivation, as well as the responses of high school students to the digestive system material. This study used an experimental method with a research one group pretest-posttest design. The research subjects were 66 students of high school, with all students getting treatment. The parameters measured are learning outcomes, learning motivation, student responses, and the relationship between learning motivation and learning outcomes. The learning outcomes data were analyzed using parametric statistics, namely Paired Sample Test, the level of learning motivation and the responses of students were analyzed using the motivation score and response guidelines. The relationship between learning motivation and learning outcomes is seen through correlation and regression analysis. The results showed that between the pretest and posttest students, as well as between the pretest and n-gain there was a significant difference in mean. The correlation coefficient shows that there is a positive relationship between learning motivation and learning outcomes. The application of webquest-based teaching materials on the digestive system can improve learning outcomes and learning motivation, learning motivation has a positive effect on learning outcomes, and gets a good response from students.
\end{abstract}

Keywords: Webquest, Learning Motivation, Student Response.

\section{INTRODUCTION}

Students' learning motivation has an important role in the learning process. Learning motivation has an influence on the success of student learning activities. Without motivation, optimal learning success will be difficult to achieve1. Furthermore, Sjukur (2012) states that motivation is an internal process that activates, guides, and maintains behavior from time to time. Motivation determines the actions we will take on something we hope for, motivation provides encouragement to achieve something we want. Students who have high learning motivation will make various efforts so that the desired learning outcomes can be 
achieved2. This is in accordance with Aritonang (2008) which states that learning motivation has a huge influence on learning outcomes3.

Based on preliminary observations made at some high school, it was found that in the digestive system material, the number of students who could not meet the minimum completeness criteria (KKM) was higher than other materials. The KKM value that must be achieved is 70 , but the data shows that there are $60 \%$ of students who do not complete the learning process of the digestive system. This shows that student motivation is still low and has an impact on student learning outcomes. Learning strategies need to be developed, monotonous learning strategies without developing learning media, learning methods, and teaching techniques will result in low learning motivation and lead to low learning outcomes4.

The results of the interview with the biology teacher at some high school said that the material of the digestive system was one of the difficult materials that was not attractive to students and was difficult to understand, so there were many obstacles in the process of implementing the learning process. Students of that school also expressed the same thing when interviewed, the material of the digestive system is dominated by types of enzymes with different functions in each organ involved in the process, so it needs a thorough understanding so that it can be fully understood. This is supported by the statement of Susilawati et al. (2015) who argues that the concept of the digestive system is very complex and complicated by rote memory so that it is difficult for students to understand5. Furthermore, Adhi and Juannita (2017) said that studying the digestive system has its own obstacles because the material is considered less attractive to children, so that the right teaching methods and media are needed. The teaching medium that has been used so far is in the form of modules, so that students can only read without seeing the digestive process that is taking place. Teaching media that can display the digestive process are needed so that students have a complex understanding of the digestive system. One of the teaching media that can be used is webquest6.

Learning using webquest teaching media can create active and student-centered learning, so that it is expected to increase student motivation which has an impact on improving student learning outcomes. This is in line with the opinion of Badiyepeymaie et al. (2016) which states that webquest can be used as an effort to use modern technology in education to encourage creativity, development, investigation, analysis, reflection, synthesis, and evaluation7. Furthermore Soepriyanto (2018) said that Webquest is a type of webbased learning that utilizes existing resources on the internet.

Several studies on the application of webquest-based teaching materials that examine the improvement of student learning outcomes and motivation have been carried out in learning English (Goktepe, 2013; Hadriana, 2016; Amadi, et al., 2017; Irzawati, 2013; Asunka, 2016; Göktepe, 2014; Hamdu \& Agustina, 2011; Inayah et al., 2013; Raisa et al, 2017; Sen \& Neufeld, 2006; Susilawati et al, 2015). The study results only reveal the overall use and function of the webquest. Meanwhile, studies that examine the use of webquests in increasing motivation and learning outcomes of the digestive system have not been carried out. Therefore, this study was conducted to prove that the application of webquest-based teaching materials can improve learning outcomes and student motivation in the digestive system material.

\section{RESEARCH METHOD}

This research uses a quantitative approach with the type of applied research, applied research is research based on problems which develops in society which aims to solve problems and the results can be used for the benefit of society. The research method used is experimental with One-group pretest-posttest design. The research was conducted in one of the senior high schools in Banda Aceh Regency, Indonesia.Study duration even semester of the 2019/2020 school year. Sample size 347 students divided into 14 study groups with details, 5 study groups for class $\mathrm{X}, 4$ study groups for class $\mathrm{XI}$, and 5 class XII study groups. The population in this study is all students from one senior high school in Banda Aceh Regency. The sample of this study was taken using a total sampling technique from a total homogeneous population.

Data collection techniques to obtain learning outcomes are carried out by comparing students' initial abilities (before being given treatment) with students' final abilities after being given treatment, what must be done is: (1) conducting pretest activities to collect data on students' initial abilities and (2) carry out posttest activities to collect students' final abilities. The instrument used was a test kit. Meanwhile, student learning motivation is measured using a questionnaire.

\section{DATA AND ANALYSIS}

When performing data analysis, tabulation must first be performed. Tabulation is the arrangement of data in table form so that the next steps can be taken. Tabulation is carried out on the results of the pretest score (learning outcomes) and posttest scores (learning outcomes and final data on learning motivation). Then 
calculate the difference between the post-test score and the pretest score (Gain) and carry out the normalization of Gain (N-Gain). The data used to see the increase in learning outcomes and student motivation are pre-test and post-test results. The gain index calculation aims to determine the range of values between the pretest and posttest. The formula for calculating the N-gain is as follows Meltzer (2002).

$$
\mathrm{N} \text { - gain }=\frac{\text { Post }- \text { test }- \text { Score Pretest }-}{\text { score } \text { Maximum Score-Class-pretest score }} X 100
$$

Nacquisition criteria scores-Gain are presented in Table-1.

Table-1. Acquisition Category Score N-Gain

\begin{tabular}{|c|c|}
\hline Limitation & Category \\
\hline $\mathrm{g}>0.7$ & High \\
\hline $0.3<\mathrm{g} \leq 0.7$ & Medium \\
\hline$\leq 0.3 \mathrm{~g}$ & Low \\
\hline
\end{tabular}

Source: Archambault $(2008)^{15}$

\section{Normality Test}

The normality test is a test carried out with the aim of assessing the distribution of data in a group of data. Normally distributed data can be performed in parametric tests using paired sample t-test. Meanwhile, data that are not normally distributed must go through non-parametric tests. The normality test used is the Kolmogorov-Smirnov test (Sugiyono, 2014). Data is said to be normal, if the significant value is greater than $0.05(P>0.05)$. Conversely, if the significant value is less than 0.05 at $(P<0.05)$, then the data is said to be abnormal.

\section{Different Test T-test}

Paired sample T-test is a test that is carried out on paired samples. The paired data sample is data before treatment (pre-test) and data after treatment (post-test). Statistical testing was performed using SPSS with a significance level $(\alpha)$ of error tolerance of 0.05 . Conclusions from the hypothesis test carried out with a significant value $\geq 0.05$, then $\mathrm{HO}$ is accepted (there is no difference) and if the significant value is $<0.05$ then $\mathrm{HO}$ is rejected (there is a difference).

\section{Correlation Test}

Correlation test is a test conducted to see the relationship between the independent variable and the dependent variable. The independent variable in this study is learning motivation, while the dependent variable is student learning outcomes. Statistical test to test the correlation hypothesis used correlation test with the following formula.

$$
r=\frac{\mathrm{n} \sum \mathrm{XY}-\left(\sum \mathrm{X}\right)\left(\sum \mathrm{Y}\right)}{\sqrt{\left[n \sum X^{2}-\left(\sum X\right)^{2}\right]\left[n \sum Y^{2}-\left(\sum Y\right)^{2}\right]}}
$$

\section{Description:}

$r_{x y}:$ calculated correlation coefficient

$\mathrm{N}$ : number of subjects calculated

$\mathrm{X}$ : variable value $\mathrm{X}_{1}$

$Y$ : variable value $Y_{1}$

The correlation coefficient interpretation criteria proposed by Sugiyono (2013) are in the table below:

Table-2. Criteria for correlation coefficient

\begin{tabular}{|c|c|}
\hline Interval Coefficient & Relationship Level \\
\hline $0.00-0.199$ & Very low \\
\hline
\end{tabular}




\begin{tabular}{|c|c|}
\hline $0.20-0.399$ & Low \\
\hline $0.40-0.599$ & Moderate \\
\hline $0.60-0.799$ & Strong \\
\hline $0.80-1,000$ & Very strong \\
\hline
\end{tabular}

Source: Arikunto (2010).

\section{RESULT AND DISCUSSION}

\subsection{Student Learning Outcomes}

Analysis of learning outcomes performed using data in the form of pre-test scores, post test scores, and NGain. The recapitulation of the mean score of learning outcomes pre-test, post-test, and N-Gain is presented in Figure-1.

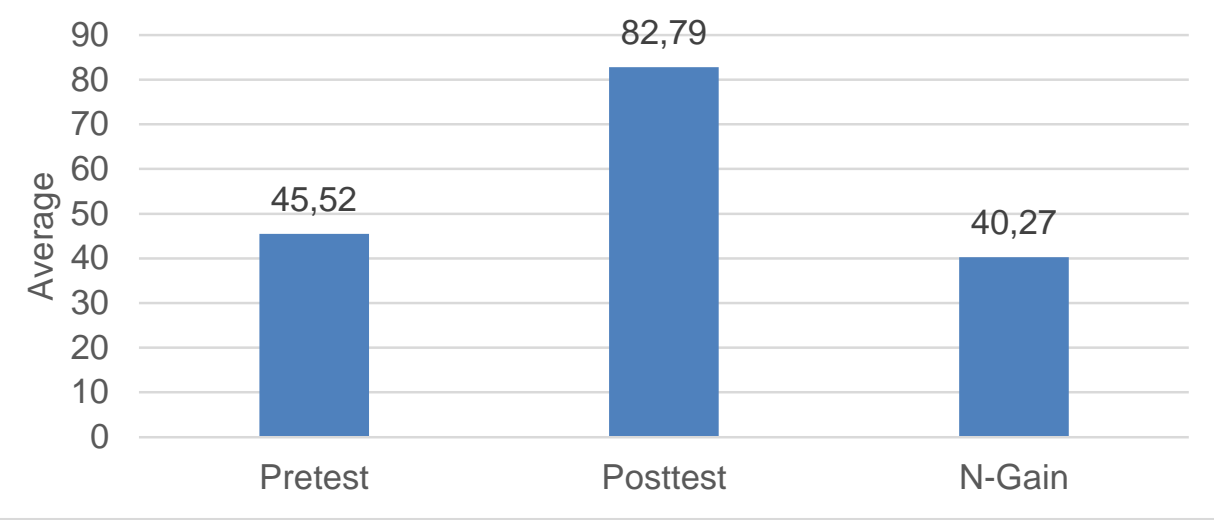

Figure-1. Average score for pretest, posttest and N-Gain of learning outcomes

The scores of pretest, posttest and N-Gain Outcomes results of the pretest, posttest, and N-Gain scores presented in Figure-1 indicate that the average pretest score is 42.52. After being given treatment in the form of learning using webquest-based teaching media and the Inquiry model, students' knowledge and understanding of the digestive system material increased compared to the pretest score. This can be seen in the average post-test score and N-Gain which is presented in Figure-1. The average posttest score is 82.79. While the average $\mathrm{N}$-Gain score was 40.27 the results of the difference in the mean pretest and posttest scores showed a significant difference. This also happened in the mean difference test between the pretest and N-Gain scores which also showed a significant difference (Table-3).

Table-3. Summary of different test average pretest, posttest, and N-Gain.

\begin{tabular}{|c|c|c|c|c|}
\hline $\begin{array}{c}\text { Results } \\
\text { Learning }\end{array}$ & $\begin{array}{c}\text { Value } \\
\text { Average }\end{array}$ & Normality & T-test & Information \\
\hline Pretest & 42.5 & $\begin{array}{c}0.093>0.05 \\
(\text { Normal })\end{array}$ & \multirow{3}{*}{$\begin{array}{c}\text { Pretest \& Posttest } \\
\mathrm{t}_{\text {count }}(32.24)>\mathrm{t}_{\text {table }}(1.99) \\
\text { Pretest \& N-Gain } \\
\mathrm{t}_{\text {countt }}(17.43)>\mathrm{t}_{\text {table }}(1.99)\end{array}$} & \multirow{3}{*}{$\begin{array}{l}\text { Significant } \\
\text { Difference }\end{array}$} \\
\hline Posttest & 82.8 & $\begin{array}{c}0.086>0.05 \\
(\text { Normal) }\end{array}$ & & \\
\hline N-Gain & 81.22 & $\begin{array}{c}0.074>0.05 \\
\text { (Normal) }\end{array}$ & & \\
\hline
\end{tabular}

Criteria owned by the N-Gain score is included in the high criteria if it is reviewed based on the N-Gain score criteria of ${ }^{15}$. The high criterion of the $\mathrm{N}$-Gain score shows that student learning outcomes have increased after being given treatment. Based on this, it can be concluded that there is an increase in student learning 
outcomes on the digestive system material after the use of webquest-based teaching media assisted by the inquiry learning model.

\subsection{Learning Motivation}

Data on students' learning motivation were obtained from the results of providing a learning motivation questionnaire as many as 40 statements which were compiled based on the ARCS learning motivation indicators. The learning motivation questionnaire was distributed after the learning process was carried out using the webquest teaching media assisted by the inquiry model. Based on the acquisition of research data collected through a questionnaire, data analysis was carried out using the descriptive technique of categories and percentages of ${ }^{17}$. The results of the analysis of student learning motivation data can be seen in Figure-2.

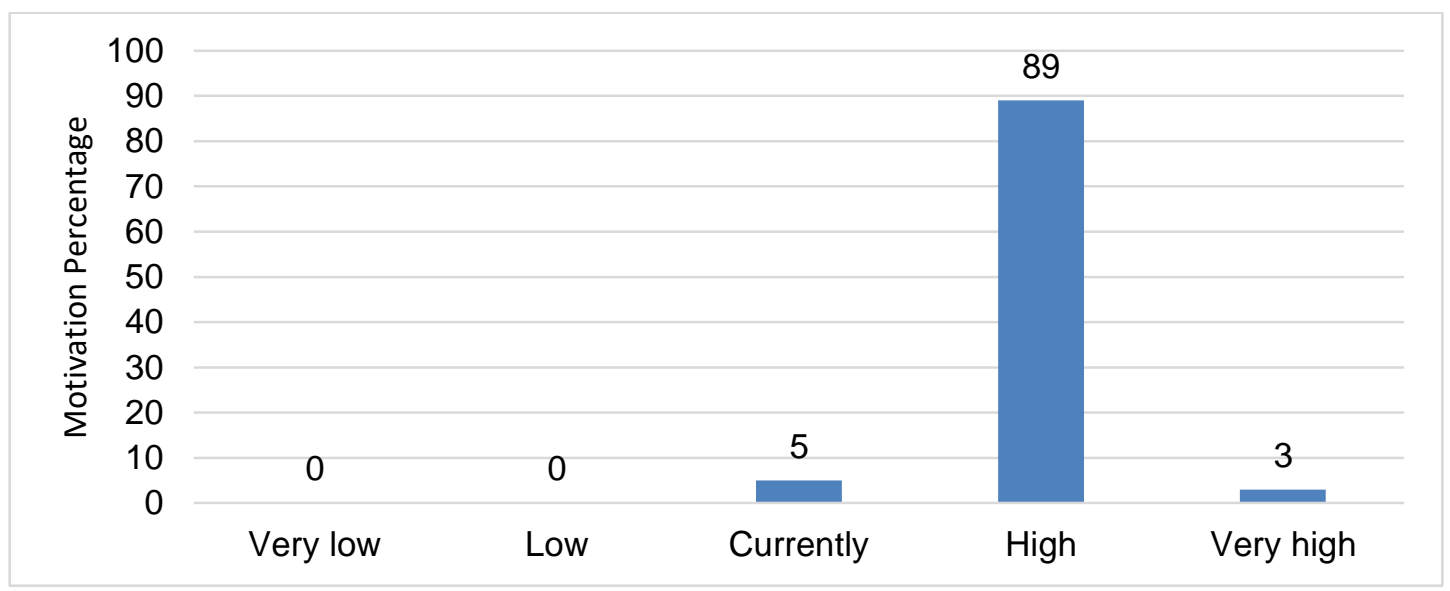

Figure-2. Graph of Subject Distribution Based on Motivation Level

Based on Table 4 and Figure 2, it can be seen that there are no students who have learning motivation in the very low and low categories, students who have learning motivation in the medium category are $8 \%$, student learning motivation is in the high category by $89 \%$, while in the very high category it was $3 \%$. This shows that with the use of inquiry-based webquest teaching media, students have high learning motivation.

\subsection{The Relationship between Learning Motivation and Student Learning Outcomes.}

Learning motivation is one of the success factors of students in achieving maximum learning outcomes. To prove the relationship between learning motivation and learning outcomes, a correlation test must be carried out. The results of the correlation test of learning motivation and learning outcomes are shown in Table-4.

Table-5. Correlation of Learning Motivation and Learning Outcomes.

\begin{tabular}{|c|c|c|c|c|}
\hline Groups & Motivation $(\mathbf{X})$ & $\begin{array}{c}\text { Learning } \\
\text { Outcomes }(\mathbf{Y})\end{array}$ & Correlation $(\mathbf{r})$ & $\begin{array}{c}\text { Coefficient } \\
\text { Correlation }\left(\mathbf{r}^{2}\right)\end{array}$ \\
\hline Value & 5493 & 5464 & 0.786 & 0.618 \\
\hline
\end{tabular}

Results the correlation test between learning motivation and learning outcomes is shown in Table 5, it is obtained $r=0.786$. Based on the correlation criteria16, there is a relationship between learning motivation and learning outcomes with a strong category. The next test that will be carried out is a statistical test of the correlation between learning motivation and learning outcomes. The t-test is conducted to see whether the relationship is significant or not between learning motivation and learning outcomes. The results of the t test can be seen in Table- 6 .

Table-6. Test of the Correlation of Learning Motivation and Learning Outcomes of Learning

\begin{tabular}{|c|c|c|c|c|}
\hline Group & Motivation $(\mathrm{X})$ & Learning Outcomes $(\mathrm{Y})$ & t-test & Information \\
\hline Value & 5493 & 5464 & $\mathrm{t}$-count (10.17) >t-table (1.99) & Significant \\
\hline
\end{tabular}

Based on Table 6 can be concluded that there is a significant relationship between learning motivation and 
learning outcomes. This can be seen from the statistical test results of the correlation between learning motivation and learning outcomes, namely t-count (10.17) > t-table (1.99). The results of the regression analysis show motivation and learning outcomes of students have a strong correlation, with the regression equation is $y=0.393 x+50.02$.

Webquest teaching media has stages that can be used as an effort to encourage creativity, investigation, development, synthesis, analysis, reflection, and evaluation. In addition, there are features that can be used to support the learning process. The webquest teaching media used in this study had instructional videos, supporting journals for learning materials, student worksheets, and the evaluation process. This is in accordance with the stages of the webquest, so that the knowledge construction process of students can be carried out (Mulyani et al, 2012).

Learning is carried out not only using webquest teaching media, but also combined with the inquiry learning model, so that in its implementation students are divided into several study groups, each of which consists of 4 or 5 students who have various abilities. Each group will get assignments that can be accessed via the webquest. The tasks that are obtained will then be studied, researched, and discussed in groups, assignments carried out by students on the webquest with an inquiry model through several stages. Students in each group must understand the problems contained in the topic, the problems presented can be in the form of discourse or video. The next stage after examining the problem, students must be able to formulate a problem formulation. After determining the formulation of the problem, students are asked to formulate a hypothesis.

Furthermore, students will collect data, test hypotheses and make conclusions. The teaching materials needed by the group to support the task completion process are available on the webquest teaching media. The final stage, students of each group will then be asked to present the results of the group work in front of the class so that a discussion process occurs, the group that has the best score will get an award (Siagian \& Nurfitriyanti, 2010). This of course encourages students to be more active in the classroom because the teacher only acts as a facilitator who facilitates students in finding material concepts based on the problems posed (Suhada, 2017). Understanding the concept of learning material is the goal of using webquest teaching media assisted by the inquiry model, it has a positive impact on improving student learning outcomes.

Digestive system matter is very complex and intricate material. In addition, the digestive system is also an abstract teaching material, so it requires appropriate teaching media and learning models so that the digestive system material, which was originally abstract for students, becomes concrete science (Susilawati et al., 2015).

Based on the research results, the use of webquest teaching materials assisted by the inquiry learning model on the digestive system material has a positive impact on students' understanding. This is because in the webquest teaching media there are learning videos which also have an important role in changing the abstract digestive system material into material that students can understand in real terms. One of the learning videos contained in the webquest illustrates the digestive process very well and is easy to understand. The video illustrates precisely and in detail each step that food goes through in the digestive process. Each enzyme involved is identified with its exact source and function, besides the digestive organs involved are well described, so that the digestive process becomes a concrete science for students. It also aims to equalize students' understanding in order to avoid concept misunderstandings. Based on the results of research that has been carried out and supported by previous research, it can be concluded that the use of webquest-based teaching materials assisted by the inquiry model can create interesting and fun learning so as to improve student learning outcomes.

The high motivation to learn is influenced by intrinsic factors that come from the individual, and extrinsic factors that can arise from outside the individual. One of the extrinsic factors of learning motivation is the right teaching media in accordance with the desires and needs of students, so that students have high learning motivation as expected. Teaching media that can increase student learning motivation are attractive, innovative teaching media, make learning centered on students, and facilitate active learning. The webquest teaching media combined with the inquiry learning model is the right step in creating interesting, studentcentered learning, and facilitating active learning, so that it has an impact on high learning motivation in students.

Motivation to learn in students using the webquest teaching media is because through the webquest students easily understand the digestive system material which is complex and abstract. The webquest used in this study is combined with the inquiry learning model, so that learning activities carried out by students 
are not only interesting, but can also encourage students to learn through active involvement with concepts and principles, students are also encouraged to have experience and experience. conducted experiments that allowed students to discover principles for themselves (Suhada, 2017).

The existence of high learning motivation from students is expected to be able to motivate students' interest in learning so that students can make school and learning a necessity and not just a demand. The more precise the motivation is given, the more successful the learning process will be. So it can be said that motivation will always determine the intensity of student learning efforts so that it will have an impact on student learning outcomes (Palupi at al., 2014). This is because motivation has a very important role in the learning process of students, motivation determines things that can be used as learning reinforcement, clarifies the learning objectives to be achieved, determines the influence on learning stimulation, and determines learning persistence.

The learning process is carried out using teaching media that students are interested in, so that the learning motivation that is formed has an impact on increasing learning outcomes. When learning to use the webquest and inquiry model, students solve problems themselves based on the discourse contained in the webquest. Webquest also provides videos that support the learning process as well as journals that help students answer problems in discourse and video inquiry. This student-centered learning makes students more responsible for the learning process. The student-centered learning process makes students feel valued and wants to show the best results from the assigned assignment. This of course triggers an increase in learning motivation and will have a positive impact on improving learning outcomes.

One of the factors that can improve learning outcomes is the existence of learning motivation, while the factors that can increase learning motivation are divided into internal factors and external factors. Internal factors come from within the individual such as psychological conditions, while external factors come from outside the individual such as teaching media and learning models. The webquest teaching media with the inquiry learning model is proven to increase learning motivation (Rubiana \& Dadi, 2020). Motivation to learn is closely related to learning outcomes, learning motivation can be a force that can be a driving force for students to maximize their potential to realize learning goals. Students who are motivated to learn will show seriousness to be involved in the learning process. So in this case motivation plays an important role in the achievement of learning outcomes because motivation is constructive, directing and supporting student learning behaviors (Prananda \& Hadiyanto, 2019).

\section{CONCLUSION}

Based on an analysis of the use of webquest-based teaching media assisted by inquiry on student learning outcomes, learning motivation, and student responses, it can be concluded that the application of WebQuest-based teaching materials can improve high school student learning outcomes on digestive system material. The application of WebQuest-based teaching materials can increase high school student learning motivation on the digestive system material. Students show a very good response to the application of WebQuest-based teaching materials on the digestive system material.

\section{REFERENCE LIST}

Adhi, B.P. \& Juannita. (2017). Development of Learning Media for the Human Digestive System for Grade 8 Junior High Schools withFeatures Augmented Reality Android-Based(Case Study: SMPN 7 Depok). Pinter's Journal, 1(1): 76-81.

Amadi, D.G. \& Paul, A.K. (2017). Perception of The Use of Webquest for Academic Purposes Among Undergraduate Students in Rivers State, Nigeria. International Journal of Education, 5(1):1-11.

Archambault, J. (2008). The Effect of Developing Kinematics Concepts Graphically Prior to Introducing Algebraic Problem Solving Techniques. Action Research Reguared for the Master of Natural Science Degree with Concentration in Physics. Arizona State University.

Arikunto, S. (2010). Prosedur Penelitian Suatu Pendekatan Praktik. Jakarta : Rineka Cipta.

Aritonang, K.T. (2008). Interest and Motivation in Improving Student Learning Outcomes. Journal of Sower's Education, 10(7):11-21.

Asunka, S. (2016). Fostering Effective Student Engagement in a first Year University Course by Harmonizing 
Web-quest Resource with Interaction: the Web-quest Approach. Journal of Advance in Business and Management Research, 3(1): 1-17.

Badiyepeymaie, J.Z.; Mosalanejad, L. \& Rezaee, R. (2016). The effect of web quest and team-based learning on students' self-regulation. Journal of Advances in Medical Education \& Professionalism, 4(2): 80-97.

Göktepe, S. (2014). 5 th World Conference on Educational Sciences - WCES 2013 A WebQuest Example for Mathematics Education. Procedia - Social and Behavioral Sciences, 11(6): 2175-2179.

Hadriana. (2015). The Effect of M-Webquest on Student Achievement in Reading Comprehension and Self Learning. Journal of educationaland Social Research, 5(3): 301-309.

Hamdu, G. \& Agustina, L. (2011). The Effect of Student Motivation on Science Learning Achievement in Elementary Schools. Journal of Educational Research, 12(1): 90-96

Inayah, R.; Martono, T.; Sawiji, H. (2013). The Influence of Teacher Competence, Student Learning Motivation, and Learning Facilities on Learning Achievement in Economics Subjects in Class XI IPS Students of SMA Negeri 1 Lasem. Journal of Insan Mandiri Education, 1(1): 1-12.

Irzawati, I. (2013). Using Webquest in Learning Grammar: Students'Perception in Higher Education. Advances in language and Literary Studies. 4(1):13-19.

Meltzer, D.E. (2002). The Relationship Between Mathematics PreparationAnd conceptual learning gain in physics:A possible inhidden Variablei in Diagnostic pretest scores. Ames: Department of physics and Astronomy, Lowa State University.

Mulyani, A.; Kamid; \& Muhamad, D. (2012). Proses Konstruksi Pengetahuan Siswa Bertipe Belajar Visual pada Pelajaran Biologi. Edu-Sains. 1(2): 1-5.

Palupi, R.; Anitah, S. \& Budiyono. (2014). Hubungan Antara Motivasi Belajar Dan Persepsi Siswa Terhadap Kinerja Guru Dalam Mengelola Kegiatan Belajar dengan Hasil Belajar Ipa Siswa Kelas Viii Di Smpn N1 Pacitan. Jurnal Teknologi Pendidikan dan Pembelajaran. 2(2):157-169.

Prananda, G. \& Hadiyanto. (2019). Korelasi Antara Motivasi Belajar dengan Hasil Belajar Siswa Dalam Pembelajaran IPA Di Sekolah Dasar. Jurnal Basicedu. 3(3): 909-915.

Raisa, S.; Adlim \& Safitri, R. (2017). Respon Peserta Didik Terhadap Pengembangan Media Audio-Visual. Jurnal Pendidikan Sains Indonesia. 5(2): 80-85.

Rubiana, E.P. \& Dadi. (2020). Faktor-Faktor yang Mempengaruhi Motivasi Belajar IPA Siswa SMP Berbasis Pesantren. Jurnal Pendidikan Biologi. 7(2): 12-17.

Sen, A. \& Neufeld, S. (2006). In Pursuit of Alternatives in ELT Methodology: WebQuest. The Turkish Online Journal of Educational Technology-TOJET, 5(1): 1-2

Siagian, R.E.F. \& Nurfitriyanti, M. (2010). Metode Pembelajaran Inquiry Dan Pengaruhnya terhadap Hasil Belajar Matematika Ditinjau dari Kreativitas Belajar. Jurnal Formatif. 2(1): 35-44.

Sjukur, S.B. (2012). The Influence of Blended LearningLearning onMotivation and Learning Outcomes of Vocational School Level Students. Journal of Vocational Education, 2(3): 368-378.

Soepriyanto, Y. (2018). Webquest Sebagai Pembelajaran Abad 21. Journal Edcomtech, 3(2): 127-133.

Sugiyono. (2014). Metode Penelitian Pendidikan Pendekatan Kuantitatif, Kualitatif, dan R\&D. Bandung: Alfabeta.

Suhada, H. (2017). Model Pembelajaran Inquiry dan Kemampuan Berpikir Kritis terhadap Keterampilan Proses Sains Siswa Kelas V pada Mata Pelajaran IPA. Jurnal Pendidikan Dasar, 8(2):13-24.

Susilawati, S.; Jumrodah \& Handayani, T.M. (2015). Comparison of the use of interactive multimedia adoption with MTsN interactive multimedia on the concept of the digestive system in MTsN 1 Model Palangkaraya. Journal of Edusains, 3(1): 37-51. 